
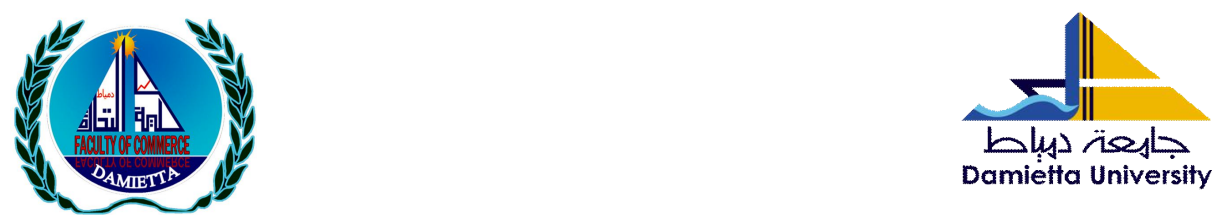

\title{
The Effect of Related Party \\ Transactions on Egyptian Firm \\ Performance: The Role of Audit Quality
}

\author{
Prepared by \\ Karim Mansour Ali Hassouba \\ Lecturer of Accounting and Finance Department \\ Faculty of Commerce, Cairo University \\ karimmansour@foc.cu.edu.eg
}

Scientific Journal for Financial and Commercial Studies and Researches (SIFCSR)

Faculty of Commerce - Damietta University

Vol.3, №.1, Part 1., January 2022

APA Citation:

Hassouba, K. M.A. (2022). The Effect of Related Party Transactions on Egyptian Firm Performance: The Role of Audit Quality , Scientific Journal for Financial and Commercial Studies and Research, Faculty of Commerce, Damietta University, 3(1)1, pp. 83-112

Website: https://cfdj.journals.ekb.eg/ 
Scientific Journal for Financial and Commercial Studies and Researches

(SJFCSR) Faculty of Commerce - Damietta University

\title{
The Effect of Related Party Transactions on Egyptian Firm Performance: The Role of Audit Quality
}

\author{
Karim Mansour Ali Hassouba
}

\begin{abstract}
The aim of this research is three-fold as (i) to test the influence of the related party transactions (RPTs) on the Egyptian firm performance (FP), (ii) to test the moderating effect of audit quality (AQ) on this relation, and (iii) to investigate the effect of transaction type and related party (RP) nature/type on FP. The research uses a sample of listed firms on the Egyptian Stock Exchange from 2013 to 2019 as the basis for the analysis. The data is analyzed using the panel corrected standards errors (PCSE), and the generalized least squares (GLS). The results suggest that (i) RPTs have a negative effect on ROA and Tobin's Q, (ii) and AQ decreases the negative effect of RPTs on ROA and increases this negative effect on Tobin's Q. (iii) Further tests show that purchase transactions with RPs positively affect ROA, while the sale transactions negatively affect ROA, additionally, there is a negative effect of the financing transactions on ROA and Tobin's Q. Concerning the effect of RP type, the results reveal that transactions with management/board and associates have a positive effect on ROA, and transactions with the joint ventures have a negative effect. Besides, the results indicate a negative effect of the transactions with the subsidiaries, joint ventures and associates on Tobin's Q. This research would help policymakers and investors; where it provides evidence about the consequences of the RPTs, also, it contributes to the existing literature of RPTs, where it provides evidence from one of the emerging markets; Egypt, on the impact of RPTs on FP.
\end{abstract}

Keywords - Related party transactions, firm performance, audit quality, Tobin' Q, ROA, Egypt. 


\section{Karim Mansour Ali Hassouba}

\section{Introduction}

Related party transactions (RPTs) are the exchange of resources, services, or obligations between the related parties (RPs), regardless of whether there is a charge for this exchange. The party is considered related to the firm if the party is directly or indirectly control or has significant influence over the firm, is under control or the joint control of the firm, is an associate of the firm or a joint venture, or is a member in the senior management of the firm or its holding company (IASB, 2013).

RPTs can have a double-edged impact on the firms (Abdul Rasheed et al., 2019; Abdullatif et al., 2019; El-Helaly, 2018; Bhuiyan and Roudaki, 2018; Marchini et al., 2018; Pozzoli and Venuti, 2014; Pizzo, 2013; Chen et al., 2011; Jian and Wong, 2010), RPTs can affect the firms negatively by exploiting the firm's resources through exercising opportunistic behavior by managers and controlling shareholders, and harm the wealth of minority shareholders, which is known as the hypothesis of the tunnel or a conflict of interests and that based on the agency theory, conversely, it may have a positive impact by reducing the cost of the transaction, facilitating the movement of goods and services between the parties, and increasing efficiency by establishing a market within the group of companies that helps to improve the firm performance (FP), which is known as the effective transaction hypothesis based on the efficient contracting theory (Chang and Hong, 2000; ElHelaly, 2018).

The varied results of prior studies that tested the effect of RPTs on FP have sparked much debate about whether or not the effect exists and what type of effect is. In this respect, some studies (Abdul Rasheed et al., 2019; Sutrisno et al., 2019; Bona-Sánchez et al., 2017; Hwang and Kim, 2016; Yaron et al., 2016; Wong and Kim, 2015) indicated that RPTs affect the FP positively by increasing the profitability and improve market performance, which supports the notion that RPTs reduce the cost of transactions. On the other hand, other studies (Tambunan et al., 2017; Al-Suraifi, 2016; Srinivasan, 2013; Abdul Elwahab et al., 2011; Utama et al., 2010; Lin et al., 2010) provided evidence that RPTs negatively affect the FP, which backs the view that RPTs exploit the firm resources and facilitate opportunistic behavior. While, according to (Diab et al, 2019; 
Scientific Journal for Financial and Commercial Studies and Researches

(SJFCSR) Faculty of Commerce - Damietta University

Pozzoli and Venuti, 2014) the effect of RPTs on FP does not exist. Regarding the relation between RPTs and FP in Egypt, there are very few studies that examined this relation, Al-Suraifi (2016) investigated the impact of RPTs disclosure on firm value (Tobin's Q) using a sample of 34 Egyptian companies during the year 2014, and found a negative influence of RPTs disclosure on the firm value. Diab et al. (2019) tested the impact of RPTs on firm value (market value), the study conducted on a sample of 30 Egyptian listed firms, and the results showed no significant effect.

The Egyptian auditing standard No. (550) indicates that the auditor should examine the information obtained from management and those responsible for governance concerning RPs, and take some procedures to verify the completeness of this information, and also pay attention to transactions that appear unusual, such as transactions that include unusual commercial terms, transactions whose substance differs from their form, and transactions with significant amounts compared to others (EFRA, 2008). Hence, this research predicts that audit quality (AQ) influences the relation between RPTs and FP, in this regard, Abdul Elwahab et al. (2011) found that auditor size could reduce the negative impact of RPTs.

It can be noticed that there is still much heated debate on the effect of RPTs on FP, as the prior literature showed mixed results regarding the existence of the effect or the type of this effect. Also, there is a lack of studies that examine the effect of AQ on the relationship between RPTs and FP. Furthermore, there are very few studies that examine the effect of RPTs on FP in the Egyptian setting, and in doing that, they used a relatively small sample and focused on the market-based measurement when measured the FP, also, there is no study either investigated the effect of the different types of RPs on Egyptian FP or the role of AQ on the relationship between RPTs and FP.

Based on that, the motivation of carrying out this study in the Egyptian setting is to provide empirical evidence about the effect of RPTs on Egyptian FP using accounting and market-based measures, and applying on a relatively large sample, also, to test the effect of AQ as one of the possible determinants of this relation, and examine the influence of transaction type (purchase, sale, and financing) and RP type (parent, 


\section{Karim Mansour Ali Hassouba}

subsidiary, joint venture, board/management, and associate) on Egyptian FP. The results of this paper may help the policymakers to impose more regulation and control over the RPTs; where such transactions would enhance /destroy the performance of firms listed on the Egyptian Stock Exchange.

The rest of this research is organized as follows: Section 2 is the literature review and hypotheses development. Section 3 introduces the research method. Section 4 presents the results. Section 5 is the discussion of results, and the last section is the conclusion.

\section{Literature Review and Hypotheses Development}

According to the rules of registering and writing off securities in the Egyptian Stock Exchange, the RPs mean all those with whom the firm has a direct or indirect relationship in one of the following cases: control of the firm, ownership of a percentage of voting rights that gives significant influence, or membership of the board or the position of CEO in the firm or its holding firm or one of its subsidiary or associates (FRA, 2020). Transactions with RPs may affect the financial position and performance of the firms because the RPs may enter into transactions that the unrelated parties may not wish to enter into (IASB, 2013), the laws allow RPTs because they are considered ordinary transactions and benefit the affiliated firms within business groups by allocating the resources effectively (Abdul Rasheed et al., 2019).

The mixed results of the earlier research have raised a great controversy about the effect of RPTs, and the literature can be categorized into three groups, the first group suggest a negative effect of the RPTs on firms, in this context, Jian and Wong (2010) mention that RPTs are high in group-controlled firms relative to other firms, and they use RPTs to manipulate earnings. Marchini et al. (2018) indicated that RPTs are correlated with earnings manipulations positively. Transactions with RPs are used as a tool of manipulation by granting loans on terms that differ from transactions with unrelated parties such as granting loans at interest rates below the market average (Shestri and Kahle, 2003; Henry et al., 2007; Gordon, 2008; Amzaleg, 2013). Mayhew (2017) indicated that RPTs are linked to future financial re-statement, and Lee et al. (2016) pointed out that RPTs lead to diminishing the degree of comparability, as it related to the excessive use of discretionary measures 
Scientific Journal for Financial and Commercial Studies and Researches

(SJFCSR) Faculty of Commerce - Damietta University

and accounting choices. According to (Huang, 2016; Williams and Taylor, 2013), RPTs help in increasing the private wealth of the insiders by providing loans and guarantee to the affiliates.

Contrariwise, the second group concluded that RPTs have a positive effect on firms, in this regard, Gordon et al. (2004) indicated that RPTs increase the quality of the transaction and reduce its cost, which makes it more effective, also, it leads to better decision-making especially in some advisory services from RPs that firms need, mostly in technologically advanced industries, moreover, the conflict of interest concerning RPTs can be reduced by increasing oversight. Limanto and Herusetya (2017) tested the association between RPTs and earnings quality, they concluded a positive relationship, but only in the case of transactions with high values. RPTs can mitigate the high costs of firms in emerging markets to obtain the necessary inputs such as finance and technology (Khanna and Palepu, 2000; Ge et al., 2010).

While the third group revealed that RPTs have no effect on firms, for example, some studies (Kuan et al., 2010, El-Helaly, 2014; Rmili, 2018) found no effect of the RPTs on earnings quality. El Helaly et al. (2018) found no significant relation between RPTs and accrual earnings management. RPTs effect may also be conditional on some factors such as specific regulatory contexts and institutional environments (Pizzo, 2013), in this regard, Dyck and Zingales (2004) indicated that the risk of RPTs is high in the case of ownership concentration and the existence of controlling shareholders.

RPTs have received great attention in Egypt, according to the executive regulations of the Capital Market Law No. 95 of 1992; firms are obliged to disclose the parties involved and the size of their transactions (FRA, 1992). The Egyptian guide of corporate governance stated that RPTs represent a type of conflict of interest, and therefore a policy must be developed to control these transactions in a manner that protects the rights of its shareholders (EIOD, 2016). The Egyptian Accounting Standard (EAS) No. 15 indicates that the financial statements of the firms must include disclosures about the nature of the RPs, and types of the current transactions (EFRA, 2016). 


\section{Karim Mansour Ali Hassouba}

Concerning the studies that investigate the impact of RPTs in Egypt, Sharaf (2020) examined the effect of RPTs on the relation between accounting information and stock prices, by using a sample of 70 Egyptian listed firms during the period from 2013 to 2016, the results showed no significant effect. Rmili, (2018) also examined the relationship between the importance and level of disclosure of RPTs on earnings quality on a sample of 31 Egyptian listed firms, and the results revealed no effect. Ali (2015) tested the relationship between the disclosure level of RPTs and the quality of financial reports using a sample of 30 Egyptian listed firms during the year 2013, the results showed a significant positive relation. Diab et al. (2019) examined the influence of RPTs on firm value, the study conducted on a sample of 30 Egyptian listed firms, the results showed no significant effect. Al-Suraifi (2016) empirically tested the influence of RPTs disclosure on firm value, using a sample of 34 Egyptian listed firms during the year 2014, the results showed a negative influence of RPTs disclosure on the firm value.

\subsection{RPTs and FP}

Previous studies that investigated the influence of RPTs on the FP did not provide conclusive evidence about the existence of this effect or its type, Abdul Rasheed et al. (2019) examined the influence of RPTs on the Indian FP for the period from 2011 to 2017, and the results showed that RPTs positively affect the FP, and also revenue income and revenue expenses by RPs positively affect the FP. According to (Hwang and Kim, 2016), RPs sales enhance the FP by increasing the earnings. Also, RPTs are more gainful than ordinary transactions and tunneling existed for RPTs which give too much compensation to RPs (Yaron et al., 2016). Wong and Kim (2015) and Bona-Sánchez et al. (2017) mention that intra-group trading relation enhances the FP, but this effect disappears if there is a high proportion of parent directors on the board. Sutrisno et al. (2019) tested the influence of RPTs on banks' performance using a sample of 40 listed Indonesian banks for the years 2013-2016, the results showed that account receivables-RPs positively affect banks' profitability and its market performance (Tobin's Q), but there are consequences of non-performing loans risk and high operating costs.

Contrariwise, Srinivasan (2013) tested the influence of RPTs in India during the period $2009-2011$ and the findings showed that RPTs 
have a negative influence on the FP. Also, Lin et al. (2010) found that RPTs affect the FP negatively. Abdul Elwahab et al. (2011) examined the relation between RPTs and the FP on a sample of Malaysian firms in the period from 2005 to 2007, and the study concluded that RPTs negatively influence the FP, similarly, Utama et al. (2010), Utama and Utama (2014), and Tambunan et al. (2017) indicated that RPTs negatively influence the Indonesian FP. Also, Al-Suraifi (2016) found a negative impact of RPTs disclosure on the Egyptian firm value.

While Hendratama and Barokah (2020) investigated the effect of RPTs on Indonesian firm value, the results revealed that RPs sales negatively affect the firm value, but when corporate social responsibility reporting exist, this relation becomes more positive, the results also indicated that RPs payables positively affect the firm value. Pozzoli and Venuti (2014) tested the influence of RPTs on the FP, using a sample of Italian listed firms for the period of 2008-2011, the results showed no effect, also, Diab et al. (2019) investigated the influence of RPTs on the Egyptian firm value, and the results showed an insignificant effect. Based on the above discussion, it is predicted that RPTs will affect the FP, hence the first hypothesis is:

$\boldsymbol{H}_{1}$ : RPTs have an impact on the performance of listed firms on the Egyptian stock exchange.

\subsection{RPTs, FP, and $A Q$}

According to Gordon et al., (2004), the conflict of interest concerning RPTs can be reduced by increasing oversight, and therefore it is expected that effective governance mechanisms will reduce the negative effect of RPTs. Chien and Hsu (2010) indicated that active corporate governance can reduce abusive RPTs and encourage RPTs which enhance operation efficiency.

The Egyptian Auditing Standard No. (550) indicated that the management is responsible for identifying and disclosing RPs and RPTs, and the auditor should design and implement auditing procedures to collect appropriate evidence concerning the management's determination and disclosure of the RPs, the impact of RPTs on the financial statements, and whether this information has been recorded and disclosed in an appropriate manner (EFRA, 2008). 


\section{Karim Mansour Ali Hassouba}

Using a sample of listed firms of the Athens Stock Exchange, ElHelaly et al. (2018) found that RPTs and real earnings management seem to be used as substitutes, but this relation is insignificant in the presence of Big 4. Bennouri et al. (2015) investigated the association between auditor reputation (Big 4) and the number of RPTs disclosed, the results showed that French firms that audited by Big 4 report fewer RPTs. Habib and Muhammadi (2018) indicated that auditors realize the risk and implications of RPTs and that reflected in more audit effort and increases the audit delay. Abdul Elwahab et al. (2011) examined the relation between RPTs, FP, and governance, on a sample of Malaysian companies in the period from 2005 to 2007 , and the study concluded that RPTs negatively affect the FP and the effective governance mechanisms can mitigate this effect, also, auditor size can diminish the negative influence of RPTs.

Based on that, it is predicted that AQ will have an impact on the relation between RPTs and the FP, hence the second hypothesis can be formulated as:

$\boldsymbol{H}_{2}$ : AQ has an impact on the relationship between RPTs and the performance of listed firms on the Egyptian stock exchange.

\section{Research Method}

\subsection{Sample Selection}

The population of this research consists of listed firms on the Egyptian stock exchange (ESE), where these firms are mandated to follow the EASs, and therefore they are required to disclose transactions with RPs. this research uses data extracted from the financial reports and the annual reports in the Thomson Reuters Eiko Database, data for 2011 and 2012 were excluded due to the events of the Egyptian revolution. Furthermore, financial institutions and banks were excluded from the sample because they are subject to disclosure requirement and regulations that differ from other sectors, the initial sample consists of all listed firms on the ESE from the year 2013 to the year 2019, after excluding banks and financial institutions and firms with missed data, the final sample becomes 735 observations which represent 105 firms. Table (1) shows the details of the sample selection. 
Scientific Journal for Financial and Commercial Studies and Researches

(SJFCSR) Faculty of Commerce - Damietta University

Table (1): Sample Selection

\begin{tabular}{|l|c|c|}
\hline & No. of firms & No. of observations \\
\hline Initial sample & 218 & 1526 \\
\hline Less: banks and financial firms & 45 & 315 \\
\hline Less: missed data & 68 & 476 \\
\hline Final sample & 105 & 735 \\
\hline
\end{tabular}

\subsection{The Research Variables and Models}

\subsubsection{The Influence of RPTs on FP}

In order to achieve the objectives of this research, the researcher used both accounting and market-based measures to provide a clear and comprehensive picture of the FP, specifically, the researcher used two measures for the FP, the first measure was the return on assets (ROA) calculated by the net operating profit to the total assets, ROA is an accounting-based measurement, backwards-looking, affected by accounting practices and focus on management outcome, the second measure was Tobin's Q calculated by the ratio of the total debt plus the market capitalization to the total assets, Tobin's Q is a market-based measurement, a forward-looking, and represents the investors assigned value to the firm's assets (Shan and Mclver, 2011).

According to Al-Matari et al., (2014), ROA is widely used as an accounting-based measurement to assess the short term FP (Rouf, 2011; Karaca and Eksi, 2012; Al Manaseer et al., 2012), and Tobin's Q is widely used as a market-based measurement to gauge the long term FP (Kang and Kim, 2011; BoZcuk, 2011). RPTs was measured by the value of RPTs to total assets (Sharaf, 2020; Rmili, 2018; Abdul Elwahab et al., 2011; Kuan et al., 2010; Gordon et al. 2004). According to (Francis and $\mathrm{Yu}, 2009$ ), Big 4 provides high audit quality, so AQ was measured as a dummy variable equals one if the firm audited by Big 4 audit firms and zero otherwise (El-Helaly et al., 2018; Bennouri et al., 2015), and also, following the literature review of RPTs and FP (Abdul Rasheed et al., 2019; Abdul Elwahab et al., 2011; Hendratama and Barokah, 2020), firm size, leverage, and sales were used as control variables. 


\section{Karim Mansour Ali Hassouba}

Based on the above, the first and second models are as follow:

$$
\begin{gathered}
R_{i t}=\beta A_{i t}+R P T S \beta 1_{i t}+A Q \beta 2_{i t}+\operatorname{SIZE} \beta 3_{i t}+L E V \beta 4_{i t}+S A L \beta 5_{i t} \\
+\varepsilon_{i t}(1) \\
\text { Tobin's } Q_{i t}=\beta 0+R P T s \beta 1_{i t}+A Q \beta 2_{i t}+S I Z E \beta 3_{i t}+L E V \beta 4_{i t}+S A L \\
\quad \beta 5_{i t}+\varepsilon_{i t}(2)
\end{gathered}
$$

Where $R O A$ is the return on assets measured by the operating income to total assets, Tobin's $Q$ is the ratio of total debt plus the market capitalization to total assets, $R P T S$ is the related party transactions measured by the value of RPTs to total assets, $A Q$ is the audit quality measured as a dummy variable equals one if the firm audited by Big 4 audit firms and zero otherwise, SIZE is the firm size measured by the log of total assets, $L E V$ is the leverage measured by the ratio of total debt to total assets, and $S A L$ is the log of sales.

\subsubsection{The Influence of AQ on the Relation between RPTs and FP}

To examine whether AQ will strengthen, weaken, or has no influence on the relation between RPTs and FP, the third and fourth models are as follow:

$$
\begin{aligned}
R O A_{i t}= & \beta O+R P T_{s} \beta 1_{i t}+A Q R P T s \beta 2_{i t}+A Q \beta 3_{i t}+\operatorname{SIZE~} \beta 4_{i t}+L E V \beta 5_{i t} \\
& +S A L \beta 6_{i t}+\varepsilon_{i t}(3)
\end{aligned}
$$

Tobin's $Q_{i t}=\beta 0+R P T s \beta 1_{i t}+A Q R P T s \beta 2_{i t}+A Q \beta 3_{i t}+\operatorname{SIZE} \beta 4_{i t}$ $+L E V \beta 5_{i t}+S A L \beta 6_{i t}+\varepsilon_{i t}(4)$

Where $A Q R P T S$ is an interactive variable used to test the moderating effect of AQ on the relationship between RPTs and FP.

\subsubsection{The Influence of Transaction Type with the RP on FP}

The researcher performs an additional test to examine the effect of transaction type with the RPs (whether it was purchase, sale, or financing) on FP, the transaction type was measured by the transaction's value of each type to total assets, based on that, the fifth and sixth models will be as follow:

$$
\begin{gathered}
R O A_{i t}=\beta 0+P T R P \beta 1_{i t}+\operatorname{STRP} \beta 2_{i t}+\text { FTRP }_{3} 3_{i t}+A Q \beta 4_{i t}+\operatorname{SIZE} \beta 5 \\
{ }_{i t}+\operatorname{LEV} \beta 6_{i t}+\operatorname{SAL} \beta 7_{i t}+\varepsilon_{i t}(5)
\end{gathered}
$$


Scientific Journal for Financial and Commercial Studies and Researches

(SJFCSR) Faculty of Commerce - Damietta University

Tobin's $Q_{i t}=\beta 0+\operatorname{PTRP} \beta 1_{i t}+\operatorname{STRP} \beta 2_{i t}+\operatorname{FTRP} \beta 3_{i t}+A Q \beta 4_{i t}$ $+S I Z E \beta 5_{i t}+L E V \beta 6_{i t}+S A L \beta 7_{i t}+\varepsilon_{i t}(6)$

Where $P T R P$ is the purchase transactions with related parties measured by the value of PTRP to total assets, STRP is the sale transactions with related parties measured by the value of STRP to total assets, and FTRP is the financing transactions with related parties measured by the value of FTRP to total assets.

\subsubsection{The Influence of the RP type on FP}

A further test was taken place to examine the effect of the type of the RPs (whether it was parent, subsidiary, joint venture, management/board, or associate) on the FP, the RP type was measured by the transactions' value of each RP to total assets, based on that, the seventh and eighth models will be as follow:

$$
\begin{gathered}
R O A_{i t}=\beta O+T P \beta 1_{i t}+T S \beta 2_{i t}+T J V \beta 3_{i t}+T M B \beta 4_{i t}+T A \beta 5_{i t}+A Q \\
\beta 6_{i t}+\operatorname{SIZE} \beta 7_{i t}+L E V \beta 8_{i t}+S A L \beta 9_{i t}++\varepsilon_{i t}(7) \\
\text { Tobin's } Q_{i t}=\beta O+T P \beta 1_{i t}+T S \beta 2_{i t}+T J V \beta 3_{i t}+T M B \beta 4_{i t}+T A \beta 5_{i t} \\
+A Q \beta 6_{i t}+\operatorname{SIZE} \beta 7_{i t}+L E V \beta 8_{i t}+S A L \beta 9_{i t}++\varepsilon_{i t}(8)
\end{gathered}
$$

Where TP is the transactions with parent measured by the value of TP to total assets, $T S$ is the transactions with subsidiary measured by the value of TS to total assets, $T J V$ is the transactions with joint ventures measured by the value of TJV to total assets, $T M B$ is the transactions with management or board measured by the value of TMB to total assets, and $T A$ is the transactions with associates measured by the value of TA to total assets. 
Karim Mansour Ali Hassouba

\section{Table (2) shows variables and measures as follows:}

Table (2): Variables Measurement

\begin{tabular}{|c|c|c|c|}
\hline \multirow[t]{2}{*}{ Variables } & & & \\
\hline & Variables & Abbreviation & Measures \\
\hline $\begin{array}{l}\text { Dependent } \\
\text { Variables }\end{array}$ & $\begin{array}{l}\text { Return on asset } \\
\text { Tobin's Q }\end{array}$ & $\begin{array}{l}\text { ROA } \\
\text { TQ }\end{array}$ & $\begin{array}{l}\text { Operating income to total } \\
\text { assets } \\
\text { The ratio of total debt plus } \\
\text { the market capitalization } \\
\text { to total assets }\end{array}$ \\
\hline \multirow[t]{9}{*}{$\begin{array}{l}\text { Independent } \\
\text { Variables }\end{array}$} & $\begin{array}{l}\text { Related parties } \\
\text { transactions }\end{array}$ & RPTs & $\begin{array}{l}\text { Value of RPTs to total } \\
\text { assets }\end{array}$ \\
\hline & $\begin{array}{l}\text { Purchase } \\
\text { transactions with } \\
\text { related parties }\end{array}$ & PTRP & $\begin{array}{l}\text { Value of PTRP to total } \\
\text { assets }\end{array}$ \\
\hline & \begin{tabular}{lr}
\multicolumn{2}{l}{ Sale transactions } \\
with related \\
parties
\end{tabular} & $\overline{\text { STRP }}$ & $\begin{array}{l}\text { Value of STRP to total } \\
\text { assets }\end{array}$ \\
\hline & $\begin{array}{l}\text { Financing } \\
\text { transactions with } \\
\text { related parties }\end{array}$ & $\overline{\text { FTRP }}$ & $\begin{array}{l}\text { Value of FTRP to total } \\
\text { assets }\end{array}$ \\
\hline & $\begin{array}{l}\text { Transactions } \\
\text { with parent }\end{array}$ & $\mathrm{TP}$ & Value of TP to total assets \\
\hline & $\begin{array}{l}\text { Transactions } \\
\text { with subsidiary }\end{array}$ & $\mathrm{TS}$ & Value of TS to total assets \\
\hline & $\begin{array}{l}\text { Transactions } \\
\text { with joint } \\
\text { venture }\end{array}$ & TJV & $\begin{array}{l}\text { Value of TJV to total } \\
\text { assets }\end{array}$ \\
\hline & $\begin{array}{l}\text { Transactions } \\
\text { with } \\
\text { management or } \\
\text { board }\end{array}$ & TMB & $\begin{array}{l}\text { Value of TMB to total } \\
\text { assets }\end{array}$ \\
\hline & $\begin{array}{l}\text { Transactions } \\
\text { with associate }\end{array}$ & TA & $\begin{array}{l}\text { Value of TA to total } \\
\text { assets }\end{array}$ \\
\hline $\begin{array}{l}\text { Moderating } \\
\text { variable }\end{array}$ & Audit quality & $\mathrm{AQ}$ & $\begin{array}{l}\text { Dummy variable equals } \\
\text { one if the firm audited by } \\
\text { Big } 4 \text { audit firms and zero } \\
\text { otherwise }\end{array}$ \\
\hline \multirow{3}{*}{$\begin{array}{l}\text { Control } \\
\text { Variables }\end{array}$} & Firm size & SIZE & The $\log$ of total assets \\
\hline & Leverage & LEV & $\begin{array}{l}\text { The ratio of total debt to } \\
\text { total assets }\end{array}$ \\
\hline & Sales & SAL & The $\log$ of sales \\
\hline
\end{tabular}


Scientific Journal for Financial and Commercial Studies and Researches

(SJFCSR) Faculty of Commerce - Damietta University

\section{Results}

\subsection{Descriptive Analysis}

The descriptive analysis of the research variables from the period 2013 to 2019 is shown in Table (3); where the mean of ROA in the Egyptian firms is .0455 , while the mean of Tobin's Q is 1.269 . RPTs represent on average $8.4 \%$ of the total assets of the Egyptian firms included in the sample. Regarding the transaction type, the results reveal that financing transactions with RPs are the largest, with an average of $2 \%$ and a maximum of about $36 \%$, while sales transactions are the lowest. Concerning the RP type, the results show that transactions with subsidiaries represent $1 \%$ of the total assets on average, which considered the highest compared to the other RP types. Also, the descriptive analysis shows that $36.5 \%$ of the financial reports included in the sample are audited by Big 4, the means of firm size and sales are 8.9 and 8.5 respectively, and finally, the total debt represents on average $42.7 \%$ from the total assets.

Table (3): Descriptive Analysis

\begin{tabular}{|c|c|c|c|c|c|}
\hline Variable & Obs & Mean & Std. Dev. & Min & Max \\
\hline ROA & 735 & .0455028 & $.1060435-$ & .3775846 & .3948408 \\
\hline TQ & 735 & 1.269065 & .6748469 & .2652005 & 7.641449 \\
\hline RPTs & 735 & .0841292 & .1072241 & 0 & .3926017 \\
\hline PTRP & 735 & .0150389 & .051158 & 0 & .3102817 \\
\hline STRP & 735 & .0082187 & .0284682 & 0 & .2096846 \\
\hline FTRP & 735 & .0200228 & .0539882 & 0 & .3636143 \\
\hline TP & 735 & .0032283 & .0147624 & 0 & .1738027 \\
\hline TS & 735 & .0122155 & .0452324 & 0 & .3926524 \\
\hline TJV & 735 & .0000759 & .0009245 & 0 & .0169813 \\
\hline TMB & 735 & .0024861 & .0112699 & 0 & .0982084 \\
\hline TA & 735 & .0045824 & .0181518 & 0 & .2096846 \\
\hline AQ & 735 & .3659864 & .4820337 & 0 & 1 \\
\hline SIZE & 735 & 8.995504 & .7767564 & 7.354992 & 10.98351 \\
\hline LEV & 735 & .4278088 & .1443264 & .075529 & .6947543 \\
\hline SAL & 735 & 8.501309 & 1.047923 & 4 & 10.63257 \\
\hline
\end{tabular}

\subsection{Correlation}

The correlation matrix is shown in Table (4) to evaluate the strength of the relationship between the FP (measured by ROA and Tobin's Q) and all other variables: 
Karim Mansour Ali Hassouba

Table (4): Correlation Matrix

\begin{tabular}{|c|c|c|c|c|c|c|c|c|c|c|c|c|c|c|c|c|}
\hline & ROA & TQ & $\begin{array}{c}\text { RPT } \\
\text { s }\end{array}$ & \begin{tabular}{|c|} 
PTR \\
P \\
\end{tabular} & \begin{tabular}{|c|} 
STR \\
P \\
\end{tabular} & \begin{tabular}{|c|} 
FTR \\
P
\end{tabular} & $\mathrm{TP}$ & $\mathrm{TS}$ & TJV & TMB & TA & $\mathrm{AQ}$ & Size & Lev & \begin{tabular}{|c|} 
SA \\
L
\end{tabular} & VIF \\
\hline ROA & 1.00 & & & & & & & & & & & & & & & - \\
\hline TQ & \begin{tabular}{|c}
0.18 \\
$* * *$
\end{tabular} & 1.00 & & & & & & & & & & & & & & - \\
\hline RPTs & $\begin{array}{c}-0.12 \\
* * *\end{array}$ & $\begin{array}{r}-0.13 \\
* * *\end{array}$ & 1.00 & & & & & & & & & & & & & 1.20 \\
\hline $\begin{array}{l}\text { PTR } \\
\text { P }\end{array}$ & $\begin{array}{c}0.11 \\
* * *\end{array}$ & -0.01 & $\begin{array}{c}0.08 \\
* *\end{array}$ & 1.00 & & & & & & & & & & & & 1.15 \\
\hline $\begin{array}{l}\text { STR } \\
\text { P }\end{array}$ & 0.00 & -0.02 & $\begin{array}{c}0.08 \\
* *\end{array}$ & $\begin{array}{r}0.22 \\
* * *\end{array}$ & 1.00 & & & & & & & & & & & 1.18 \\
\hline $\begin{array}{l}\text { FTR } \\
\text { P }\end{array}$ & $\begin{array}{c}-0.07 \\
* *\end{array}$ & -0.04 & $\begin{array}{r}0.27 \\
* * *\end{array}$ & $\begin{array}{r}0.14 \\
* * *\end{array}$ & -0.00 & 1.00 & & & & & & & & & & 1.78 \\
\hline $\mathrm{TP}$ & -0.00 & 0.02 & $\begin{array}{r}0.10 \\
* * *\end{array}$ & $-0.04 \mid$ & $-0.01 \mid$ & $\begin{array}{r}0.36 \\
* * *\end{array}$ & 1.00 & & & & & & & & & 1.28 \\
\hline TS & -0.00 & -0.05 & $\begin{array}{r}0.25 \\
* * *\end{array}$ & $\begin{array}{r}0.16 \\
* * *\end{array}$ & $\begin{array}{r}0.24 \\
* * *\end{array}$ & $\begin{array}{r}0.49 \\
* * *\end{array}$ & 0.01 & 1.00 & & & & & & & & 1.61 \\
\hline TJV & -0.04 & -0.03 & $\begin{array}{c}0.07 \\
* *\end{array}$ & $-0.00 \mid$ & $-0.02 \mid$ & $\begin{array}{c}0.07 \\
* *\end{array}$ & $\begin{array}{r}0.13 \\
* * *\end{array}$ & 0.04 & 1.00 & & & & & & & 1.04 \\
\hline TMB & 0.05 & 0.02 & $\begin{array}{l}0.13 \\
* * *\end{array}$ & $\begin{array}{r}0.11 \\
* * *\end{array}$ & -0.03 & $\begin{array}{c}0.07 \\
*\end{array}$ & -0.04 & $-0.04 \mid$ & $-0.01 \mid$ & 1.00 & & & & & & 1.09 \\
\hline $\mathrm{TA}$ & $\begin{array}{c}0.07 \\
*\end{array}$ & -0.02 & $\begin{array}{c}0.09 \\
* *\end{array}$ & $\begin{array}{c}0.08 \\
* *\end{array}$ & $\begin{array}{r}0.39 \\
* * *\end{array}$ & $\begin{array}{r}0.09 \\
* * *\end{array}$ & 0.00 & $-0.01 \mid$ & -0.02 & -0.05 & 1.00 & & & & & 1.31 \\
\hline AQ & $\begin{array}{c}0.09 \\
* *\end{array}$ & $\begin{array}{c}0.07 \\
* *\end{array}$ & $\begin{array}{r}0.20 \\
* * *\end{array}$ & $\begin{array}{r}0.10 \\
* * *\end{array}$ & $\begin{array}{r}0.15 \\
* * *\end{array}$ & $\begin{array}{c}0.09 \\
* *\end{array}$ & $\begin{array}{r}0.12 \\
* * *\end{array}$ & $\begin{array}{r}0.11 \\
* * *\end{array}$ & $\begin{array}{r}0.10 \\
* * *\end{array}$ & $\begin{array}{r}0.13 \\
* * *\end{array}$ & $\begin{array}{r}0.12 \\
* * *\end{array}$ & 1.00 & & & & 1.38 \\
\hline SIZE & $\begin{array}{r}-0.22 \\
* * *\end{array}$ & $\begin{array}{c}0.11 \\
* * *\end{array}$ & $\begin{array}{c}0.08 \\
* *\end{array}$ & 0.01 & $\begin{array}{c}0.09 \\
* *\end{array}$ & $\begin{array}{r}0.11 \\
* * *\end{array}$ & $\begin{array}{r}0.16 \\
* * *\end{array}$ & $-0.01 \mid$ & 0.03 & 0.04 & $\begin{array}{r}0.13 \\
* * *\end{array}$ & $\begin{array}{c}0.42 \\
* * *\end{array}$ & 1.00 & & & 3.83 \\
\hline LEV & 0.01 & 0.00 & $\begin{array}{r}0.11 \\
* * *\end{array}$ & $\begin{array}{c}0.08 \\
* *\end{array}$ & $\begin{array}{c}0.12 \\
* * *\end{array}$ & $-0.00 \mid$ & $\begin{array}{r}0.10 \\
* * *\end{array}$ & $\begin{array}{c}0.06 \\
*\end{array}$ & -0.00 & $\begin{array}{r}0.10 \\
* * *\end{array}$ & 0.03 & $\begin{array}{r}0.30 \\
* * *\end{array}$ & $\begin{array}{r}0.31 \\
* * *\end{array}$ & 1.00 & & 1.21 \\
\hline SAL & $\begin{array}{c}0.36 \\
* * *\end{array}$ & $\begin{array}{c}0.08 \\
* *\end{array}$ & 0.01 & $\begin{array}{r}0.12 \\
* * *\end{array}$ & $\begin{array}{r}0.16 \\
* * *\end{array}$ & $\begin{array}{c}0.06 \\
*\end{array}$ & $\begin{array}{r}0.14 \\
* * *\end{array}$ & 0.01 & 0.02 & 0.02 & $\begin{array}{l}0.10 \\
* * *\end{array}$ & $\begin{array}{r}0.39 \\
* * *\end{array}$ & $\begin{array}{r}0.83 \\
* * *\end{array}$ & $\begin{array}{r}0.29 \\
* * *\end{array}$ & 1.00 & 3.68 \\
\hline
\end{tabular}

Note: *** significant at $1 \%$, ** significant at $5 \%$; * significant at $10 \%$

Tabl (4) Shows a positive correlation between ROA and each of PTRP,TA, AQ, and SAL. While, there is a negative correlation between ROAand each of FTRP, SIZE and RPTs, and no correlation between ROA and each of STRP, TP, TS, TJV, TMB and LEV. Also, Table (4) shows a positive correlation between Tobin's Q and each of AQ, SIZE, and SAL.While the correlation between Tobin's Q and RPTs is negative, and nocorrelation between Tobin's Q and each of PTRP, STRP, FTRP, TP, TS,TJV, TMB, TA, and LEV. Moreover, Table (4) reveals nomulticollinearity between the independent variables (VIF $<10)$. 
Scientific Journal for Financial and Commercial Studies and Researches

(SJFCSR) Faculty of Commerce - Damietta University

\subsection{Regression Analysis and Testing of Hypotheses}

The paper hypotheses were tested with the panel data methodology. According to the Hausman test $(\mathrm{P}>0.05)$, the Random-Effects model was used first to examine the hypotheses, the Wooldridge test for autocorrelation in panel data indicates a problem of autocorrelation (Prob $>\mathrm{F}=0.0000$ ), also, the results reveal a problem of heteroscedasticity (Prob $>$ chi $2=0.0000$ ), to solve these problems the PCSE method was used, PCSE assumes that the disturbances are by default heteroscedasticity and contemporaneously correlated across the panel.

Model (1) in Table (5) indicates a significant negative effect of RPTs on ROA. As for the effect of RPTs on Tobin's Q, model (2) shows also a significant negative influence, taken together (models 1 and 2), the first hypothesis is accepted, so there is a negative influence of RPTs on FP, these results are in agreement with the results of some studies conducted in India, Malaysia, Indonesia and Egypt such as (Srinivasan, 2013; Abdul Elwahab et al., 2011; Utama et al., 2010; and Al-Suraifi, 2016). Concerning the influence of the control variables, it is clear from Table (5) that LEV negatively affects ROA, while, SAL has a positive influence, these results are consistent with (Abdul Rasheed et al, 2019) and (Abdul Elwahab et al, 2011). SIZE negatively affects ROA, contrastingly, it has a positive influence on Tobin's Q, which in line with (Hendratama and Barokah, 2020), and the results also show no effect of LEV and SAL on Tobin's Q.

Respecting the effect of AQ on the relation between RPTs and FP, Model (3) in Table (5) shows that AQ has a positive influence on the relation between RPTs and ROA, this means that the negative influence of RPTs on ROA is weakened when the firm is audited by Big 4, this finding supports the result of (Abdul Elwahab et al., 2011), who found that Big 4 can diminish the negative influence of RPTs on Malaysian FP. contradictorily, model (4) indicates that AQ has a negative influence, this means that AQ will increase the negative influence of RPTs on Tobin's Q, taken together (models 3 and 4), the second hypothesis is accepted, therefore, AQ has an effect on the relation between RPTs and FP, this effect is positive on ROA and negative on Tobin's Q. 


\section{Karim Mansour Ali Hassouba}

Table (5) shows an additional analysis to examine the effect of the transaction type (whether it was purchase, sale, or financing) on FP, model (5) indicates a positive effect of purchase transactions with RPs on ROA and a negative effect of financing transactions. Also, different from (Hwang \& Kim, 2016) and (Abdul Rasheed et al, 2019), the results reveal that sale transactions have a negative effect on ROA. While model (6) shows a negative effect of financing transactions on Tobin's Q and no effect for purchase or sale transactions, this finding regarding the effect of sale transactions is not matching with the results of (Hendratama and Barokah, 2020).

Table (5) shows another additional analysis to test the effect of the RP type (whether it was parent, subsidiary, joint venture, management/board, or associate) on FP, model (7) indicates that transactions with management/board and associates have a positive effect on ROA, and transactions with the joint venture have a negative effect, while transactions with parent and subsidiary do not affect ROA. Regarding the effect of RP type on Tobin's Q, the results of the model (8) indicate a negative effect for the transactions with the subsidiary, joint venture and associates on Tobin's Q, and no effect for the transactions with parent and management/board. 
Scientific Journal for Financial and Commercial Studies and Researches (SJFCSR) Faculty of Commerce - Damietta University

\begin{tabular}{|c|c|c|c|c|c|c|c|c|c|c|c|c|c|c|c|c|}
\hline \multicolumn{17}{|c|}{ Table (5): Results of Regression Analysis } \\
\hline & \multicolumn{16}{|c|}{ Panel-Corrected Standard Errors (PCSE) } \\
\hline & \multicolumn{4}{|c|}{$\begin{array}{c}\text { The effect of RPTs on } \\
\text { FP }\end{array}$} & \multicolumn{4}{|c|}{$\begin{array}{c}\text { The moderating effect } \\
\text { of } \mathrm{AQ}\end{array}$} & \multicolumn{4}{|c|}{$\begin{array}{l}\text { The effect of transaction } \\
\text { type with the RP on FP }\end{array}$} & \multicolumn{4}{|c|}{$\begin{array}{c}\text { The effect of the RP type on } \\
\text { FP }\end{array}$} \\
\hline & \multicolumn{2}{|c|}{$\begin{array}{l}\text { Model (1) } \\
\text { ROA }\end{array}$} & \multicolumn{2}{|c|}{$\begin{array}{c}\text { Model (2) } \\
\text { TQ }\end{array}$} & \multicolumn{2}{|c|}{$\begin{array}{c}\text { Model (3) } \\
\text { ROA }\end{array}$} & \multicolumn{2}{|c|}{$\begin{array}{l}\text { Model } \\
\text { (4) TQ }\end{array}$} & \multicolumn{2}{|c|}{$\begin{array}{l}\text { Model (5) } \\
\text { ROA }\end{array}$} & \multicolumn{2}{|c|}{$\begin{array}{l}\text { Model (6) } \\
\text { TQ }\end{array}$} & \multicolumn{2}{|c|}{$\begin{array}{l}\text { Model (7) } \\
\text { ROA }\end{array}$} & \multicolumn{2}{|c|}{ Model (8) TQ } \\
\hline & Coef & Z & Coef & Z & Coef & Z & Coef & Z & Coef & $\mathrm{Z}$ & Coef & $\mathrm{Z}$ & Coef & $\mathrm{Z}$ & Coef & $\mathrm{Z}$ \\
\hline RPTs & -.103 & \begin{tabular}{|c|}
-4.98 \\
$* * *$ \\
\end{tabular} & -.993 & \begin{tabular}{|c|}
-5.65 \\
$* * *$ \\
\end{tabular} & -.135 & \begin{tabular}{|c|}
-5.22 \\
$* * *$ \\
\end{tabular} & -.729 & \begin{tabular}{|l|}
-4.40 \\
$* * *$ \\
\end{tabular} & - & - & - & - & - & - & - & - \\
\hline PTRP & - & - & - & - & - & - & - & - & .177 & $2.36^{* *}$ & *. 007 & 0.02 & - & - & - & - \\
\hline STRP & - & - & - & - & - & - & - & - & -.293 & $\begin{array}{c}-2.55 \\
* * \\
\end{array}$ & -.726 & -1.11 & - & - & - & - \\
\hline FTRP & - & - & - & - & - & - & - & - & -.212 & $\begin{array}{c}-3.52 \\
* * * \\
\end{array}$ & -.808 & $\begin{array}{c}-2.99 \\
* * * \\
\end{array}$ & - & - & - & - \\
\hline TP & - & - & - & - & - & - & - & - & - & - & - & - & -.208 & -0.98 & .418 & 0.42 \\
\hline TS & - & - & - & - & - & - & - & - & - & - & - & - & -.023 & -0.42 & -.787 & $-2.91^{* * *}$ \\
\hline TJV & - & - & - & - & - & - & - & - & - & - & - & - & -4.46 & $-1.98 * *$ & -32.6 & $-2.85^{* * *}$ \\
\hline TMB & - & - & - & - & - & - & - & - & - & - & - & - & .568 & $\begin{array}{l}2.94 \\
* * * *\end{array}$ & .881 & 0.26 \\
\hline TA & - & - & - & - & - & - & - & - & - & - & - & - & .287 & $2.21 * *$ & -1.86 & $-2.21 * *$ \\
\hline AQ & .001 & 0.40 & .103 & $\begin{array}{c}2.29 \\
* *\end{array}$ & -.008 & $\begin{array}{c}-1.99 \\
* * \\
\end{array}$ & .190 & \begin{tabular}{|l|}
3.41 \\
$* * *$
\end{tabular} & -.000 & -0.14 & .070 & 1.57 & -.003 & \begin{tabular}{|l|}
-0.78 \\
\end{tabular} & .079 & $\begin{array}{c}1.71 \\
*\end{array}$ \\
\hline SIZE & -.032 & $\begin{array}{c}-5.62 \\
* * * \\
\end{array}$ & .146 & $\begin{array}{l}3.54 \\
* * *\end{array}$ & -.030 & \begin{tabular}{|c|}
-5.23 \\
$* * *$ \\
\end{tabular} & .131 & \begin{tabular}{|l|}
3.04 \\
$* * *$
\end{tabular} & -.030 & $\begin{array}{c}-4.91 \\
* * *\end{array}$ & .128 & \begin{tabular}{|l|}
3.49 \\
$* * *$ \\
\end{tabular} & -.035 & \begin{tabular}{|c|}
-5.52 \\
***
\end{tabular} & .123 & $\begin{array}{l}3.38 \\
* * * * \\
\end{array}$ \\
\hline LEV & -.056 & \begin{tabular}{|c|}
-3.11 \\
$* * *$ \\
\end{tabular} & -.154 & -0.67 & -.060 & \begin{tabular}{|c|}
-3.20 \\
$* * * *$ \\
\end{tabular} & -.121 & -0.55 & -.065 & $\begin{array}{c}-3.40 \\
* * * \\
\end{array}$ & -.206 & -0.89 & -.063 & \begin{tabular}{|c|}
-3.33 \\
$* * *$ \\
\end{tabular} & -.211 & -0.97 \\
\hline SAL & .059 & \begin{tabular}{|c|}
14.9 \\
$* * *$ \\
\end{tabular} & -.048 & \begin{tabular}{|l}
-1.58 \\
\end{tabular} & .058 & \begin{tabular}{|l|}
13.8 \\
$* * * *$ \\
\end{tabular} & -.042 & -1.33 & .059 & \begin{tabular}{|c|}
14.38 \\
$* * *$
\end{tabular} & -.024 & -0.76 & .061 & $\begin{array}{l}14.3 \\
* * * \\
\end{array}$ & -.025 & -0.81 \\
\hline $\begin{array}{l}\mathrm{AQ}^{*} \mathrm{R} \\
\mathrm{PT} \text { s }\end{array}$ & - & - & - & - & .087 & \begin{tabular}{|l|}
3.28 \\
$* * *$ \\
\end{tabular} & -.722 & \begin{tabular}{|c|}
-4.02 \\
$* * *$ \\
\end{tabular} & - & - & - & - & - & - & - & - \\
\hline Cons & -.131 & -4.30 & .473 & 1.80 & -.137 & -4.54 & .522 & 1.97 & -.152 & -5.11 & .410 & 1.72 & -.133 & -4.43 & .452 & 1.79 \\
\hline $\mathrm{N}$ & \multicolumn{2}{|c|}{735} & \multicolumn{2}{|c|}{735} & \multicolumn{2}{|c|}{735} & \multicolumn{2}{|c|}{735} & \multicolumn{2}{|c|}{735} & \multicolumn{2}{|c|}{735} & \multicolumn{2}{|c|}{735} & \multicolumn{2}{|c|}{735} \\
\hline R square & \multicolumn{2}{|c|}{0.17} & \multicolumn{2}{|c|}{.039} & \multicolumn{2}{|c|}{0.17} & \multicolumn{2}{|c|}{0.04} & \multicolumn{2}{|c|}{0.18} & \multicolumn{2}{|c|}{0.020} & \multicolumn{2}{|c|}{0.17} & 0. & 02 \\
\hline $\begin{array}{l}\text { Wald } \\
\text { chi2 }\end{array}$ & 651.7 & & 64.8 & & 647 & 7.27 & 104 & 1.42 & 780 & & 84. & & 949. & .20 & 82 & .94 \\
\hline $\begin{array}{c}\text { Prob }>\text { c } \\
\text { hi2 } \\
\end{array}$ & .00 & & .000 & & .0 & 00 & .00 & 00 & .00 & & .00 & & .00 & 00 & .0 & 00 \\
\hline
\end{tabular}

\subsection{Robustness analysis}

The GLS method was used (as another estimation method) to confirm the results of the regression, GLS allows estimation in the presence of AR (1) autocorrelation with the panel and cross-sectional correlation and heteroscedasticity across panels, generally, in Table (6) the coefficients of the GLS regressions show the same sign and statistical significance of the PCSE method, especially concerning the effect of RPTs on ROA and Tobin's Q, and also the moderating effect of AQ, this confirms the robustness of the research results. 
Karim Mansour Ali Hassouba

\begin{tabular}{|c|c|c|c|c|c|c|c|c|c|c|c|c|c|c|c|c|}
\hline \multicolumn{17}{|c|}{ Table (6): Results of the Robustness Analysis } \\
\hline \multicolumn{17}{|c|}{ The Generalized Least Squares (GLS) } \\
\hline & \multicolumn{4}{|c|}{$\begin{array}{l}\text { The effect of RPTs on } \\
\text { FP }\end{array}$} & \multicolumn{4}{|c|}{$\begin{array}{c}\text { The moderating effect of } \\
\text { AQ }\end{array}$} & \multicolumn{4}{|c|}{$\begin{array}{l}\text { The effect of transaction } \\
\text { type with the RP on FP }\end{array}$} & \multicolumn{4}{|c|}{$\begin{array}{c}\text { The effect of the RP type on } \\
\text { FP }\end{array}$} \\
\hline & \multicolumn{2}{|c|}{$\begin{array}{l}\text { Model (1) } \\
\text { ROA }\end{array}$} & \multicolumn{2}{|c|}{$\begin{array}{l}\text { Model } \\
(2) \mathrm{TQ}\end{array}$} & \multicolumn{2}{|c|}{\begin{tabular}{|c|}
$\begin{array}{c}\text { Model (3) } \\
\text { ROA }\end{array}$ \\
\end{tabular}} & \multicolumn{2}{|c|}{$\begin{array}{l}\text { Model } \\
\text { (4) TQ }\end{array}$} & \multicolumn{2}{|c|}{$\begin{array}{l}\text { Model (5) } \\
\text { ROA }\end{array}$} & \multicolumn{2}{|c|}{$\begin{array}{l}\text { Model (6) } \\
\text { TQ }\end{array}$} & \multicolumn{2}{|c|}{$\begin{array}{l}\text { Model (7) } \\
\text { ROA }\end{array}$} & \multicolumn{2}{|c|}{$\begin{array}{l}\text { Model (8) } \\
\text { TQ }\end{array}$} \\
\hline & Coef & $\mathrm{Z}$ & Coef & $\mathrm{Z}$ & Coef & $\mathrm{Z}$ & Coef & $\mathrm{Z}$ & \begin{tabular}{|l|l|} 
Coef \\
\end{tabular} & $\mathrm{Z}$ & Coef & $\bar{Z}$ & \begin{tabular}{|l|l|} 
Coef \\
\end{tabular} & $\bar{Z}$ & Coef & $\mathrm{Z}$ \\
\hline RPTs & -.087 & \begin{tabular}{|c|}
-6.90 \\
$* * *$ \\
\end{tabular} & -.516 & \begin{tabular}{|c|}
-5.75 \\
$* * *$ \\
\end{tabular} & -.107 & \begin{tabular}{|c|}
-8.11 \\
$* * * *$ \\
\end{tabular} & -.435 & -4.21 & - & - & - & - & - & - & - & - \\
\hline PTRP & - & - & - & -1 & - & -1 & - & - & \begin{tabular}{|l|}
-.026 \\
\end{tabular} & -1.10 & -.252 & $\begin{array}{l}-1.46 \\
\end{array}$ & - & - & - & - \\
\hline STRP & - & - & - & - & - & - & - & - & -.057 & -1.07 & .006 & 0.02 & - & - & - & - \\
\hline FTRP & - & - & - & - & - & - & - & - & -.116 & \begin{tabular}{|l|}
-5.78 \\
$* *$
\end{tabular} & -.193 & \begin{tabular}{|l|}
-0.92 \\
\end{tabular} & - & - & - & - \\
\hline TP & - & - & - & - & - & - & - & - & - & - & - & - & \begin{tabular}{|l|l|}
-.026 \\
\end{tabular} & \begin{tabular}{|l|}
-0.42 \\
\end{tabular} & \begin{tabular}{|l|}
-.606 \\
\end{tabular} & -1.03 \\
\hline TS & - & - & - & - & - & - & - & - & - & - & - & - & \begin{tabular}{|l|}
-.059 \\
\end{tabular} & \begin{tabular}{|l|l|} 
\\
\end{tabular} & \begin{tabular}{|l|}
-.132 \\
\end{tabular} & -0.63 \\
\hline TJV & - & - & - & - & - & - & - & - & - & - & - & - & \begin{tabular}{|l|l|}
-2.12 \\
\end{tabular} & \begin{tabular}{|l|}
-0.94 \\
\end{tabular} & \begin{tabular}{|l|}
-18.8 \\
\end{tabular} & -1.59 \\
\hline TMB & - & - & - & - & - & - & - & - & - & - & - & - & \begin{tabular}{|l|}
-.280 \\
\end{tabular} & \begin{tabular}{|c|}
-2.04 \\
$* *$
\end{tabular} & -.555 & -0.47 \\
\hline TA & - & - & - & - & - & - & - & - & - & - & - & - & .040 & 0.58 & \begin{tabular}{|l|}
-1.19 \\
\end{tabular} & $-1.98^{* *}$ \\
\hline $\mathrm{AQ}$ & -.010 & $\begin{array}{c}-1.77 \\
* \\
\end{array}$ & -.030 & -0.69 & -.011 & \begin{tabular}{|c|}
-2.10 \\
$* *$ \\
\end{tabular} & $\mid-.006$ & $\mid-0.14$ & -.013 & \begin{tabular}{|c|}
-2.56 \\
$* *$ \\
\end{tabular} & -.038 & \begin{tabular}{|l|}
-0.92 \\
\end{tabular} & -.011 & \begin{tabular}{|c|}
-2.18 \\
$* *$
\end{tabular} & \begin{tabular}{|l|}
-.013 \\
\end{tabular} & -0.32 \\
\hline SIZE & -.032 & \begin{tabular}{|l|}
-6.44 \\
$* * * *$
\end{tabular} & .079 & $\begin{array}{c}2.15 \\
* *\end{array}$ & -.034 & \begin{tabular}{|l|}
-6.90 \\
$* * * *$ \\
$* 2 * *$
\end{tabular} & .071 & $\begin{array}{c}1.85 \\
*\end{array}$ & -.035 & \begin{tabular}{|c|}
-8.04 \\
$* * * *$ \\
\end{tabular} & .067 & $\begin{array}{c}1.66 \\
*\end{array}$ & -.031 & \begin{tabular}{|c|}
-6.66 \\
$* * * *$
\end{tabular} & .099 & $\begin{array}{c}2.42 \\
* *\end{array}$ \\
\hline LEV & -.012 & -1.10 & .027 & 0.45 & -.011 & -0.96 & \begin{tabular}{|l|}
.026 \\
\end{tabular} & 0.41 & \begin{tabular}{|l|}
-.018 \\
\end{tabular} & $0.05 *$ & -.008 & -0.14 & \begin{tabular}{|l|}
-.014 \\
\end{tabular} & -1.55 & \begin{tabular}{|l|}
-.039 \\
\end{tabular} & -0.63 \\
\hline SAL & .056 & \begin{tabular}{|c|}
16.34 \\
$* * *$ \\
\end{tabular} & -.004 & -0.18 & .056 & \begin{tabular}{|c|}
16.7 \\
3
\end{tabular} & -.005 & -0.21 & .059 & \begin{tabular}{|c|}
17.38 \\
$* * *$ \\
\end{tabular} & .018 & 0.68 & .055 & $\begin{array}{l}15.8 \\
* * *\end{array}$ & .005 & 0.22 \\
\hline $\begin{array}{c}\mathrm{AQ} * \mathrm{R} \\
\mathrm{PT} \\
\end{array}$ & - & - & - & - & .036 & \begin{tabular}{|l|}
2.81 \\
$* * *$
\end{tabular} & -.171 & $\mid-1.61$ & - & - & - & - & -.139 & 0.00 & .271 & 1.13 \\
\hline $\begin{array}{l}\text { Cons } \\
\end{array}$ & -.132 & -3.93 & .526 & 2.11 & -.114 & $\mid-3.52$ & \begin{tabular}{|l|}
.594 \\
\end{tabular} & 2.33 & \begin{tabular}{|l|}
-.125 \\
\end{tabular} & -4.00 & .439 & 1.82 & \begin{tabular}{|l|}
-.026 \\
\end{tabular} & -0.42 & \begin{tabular}{|l|}
-.606 \\
\end{tabular} & -1.03 \\
\hline $\mathrm{N}$ & \multicolumn{2}{|c|}{735} & \multicolumn{2}{|c|}{735} & \multicolumn{2}{|c|}{735} & \multicolumn{2}{|c|}{735} & \multicolumn{2}{|c|}{735} & \multicolumn{2}{|c|}{735} & \multicolumn{2}{|c|}{735} & \multicolumn{2}{|c|}{735} \\
\hline $\begin{array}{l}\text { Model } \\
\text { Sig }\end{array}$ & \multicolumn{2}{|c|}{.000} & \multicolumn{2}{|c|}{.000} & \multicolumn{2}{|c|}{.000} & \multicolumn{2}{|c|}{.000} & \multicolumn{2}{|c|}{.000} & \multicolumn{2}{|c|}{.046} & \multicolumn{2}{|c|}{.000} & & 18 \\
\hline $\begin{array}{l}\text { Wald } \\
\text { chi2 }\end{array}$ & 343. & & 39.3 & & 371.2 & & 34.2 & & 352. & & 14. & & 291. & .03 & 19. & 96 \\
\hline $\begin{array}{l}\text { Prob }>c \\
\text { hi2 } \\
\end{array}$ & .00 & & .00 & & .00 & & .000 & & .000 & & .04 & & .00 & 00 & 01 & 18 \\
\hline
\end{tabular}

\section{Discussion}

This paper endeavors to examine the influence of RPTs on FP (measured by ROA and Tobin's Q) of the Egyptian firms, and also to examine the impact of AQ on this relation, the paper also aims to investigate the effect of both transaction type and RP type on FP, I have predicted that RPTs will affect the FP, Model (1) in Table (5) indicates that the coefficient of RPTs is significant and negative which means that RPTs decrease ROA, also, the coefficient of RPTs in Model (2) is significant and negative, which means that RPTs decrease Tobin's Q, this can be clarified that RPTs facilitate exploiting the firm's resources through exercising opportunistic behavior by managers and controlling shareholders and harm the wealth of minority shareholders (Jian and Wong, 2010; Marchini et al, 2018; Shestri and Kahle, 2003; Henry et al, 2007; Gordon, 2008; Amzaleg, 2013; Huang, 2016; Williams and Taylor, 
Scientific Journal for Financial and Commercial Studies and Researches

(SJFCSR) Faculty of Commerce - Damietta University

2013), which means that RPTs represent a conflict of interest under the agency theory, these results also are consistent with the results of (Utama et al, 2010; Lin et al., 2010; Abdul Elwahab et al, 2011; Srinivasan, 2013; Utama and Utama, 2014; Tambunan et al, 2017), who found a negative effect of RPTs on FP, and also, in agreement with (Al-Suraifi, 2016) who found that RPTs negatively affect the value of Egyptian firm, on the other hand, these results contradict the findings of (Abdul Rasheed et al, 2019; Hwang and Kim, 2016; Wong and Kim, 2015; Sutrisno et al., 2019).

Regarding the effect of AQ on the relation between RPTs and FP, Model (3) in Table (5) shows that the coefficient of AQRPT is significant and positive, so the negative influence of RPTs on ROA is reduced when the firm is audited by Big 4, this result is in line with (Abdul Elwahab et al, 2011), this means that Big 4 can reduce the risk of RPTs (Habib and Muhammadi, 2018), and also supports the notion that corporate governance efficiency can decrease abusive RPTs and smooth RPTs which enhance operations (Gordon et al, 2004; Chien and Hsu, 2010). Inversely, model (4) indicates that the coefficient of AQRPT is significant and negative, this means that AQ will increase the negative effect of RPTs on Tobin's Q, a possible explanation of this result can be as follow: the increase in the audit quality may lead the auditor to include notes in his report about the negative impact of the RPTs, which may result in a negative market reaction and may reflect in the decline in the stock prices and thus reduce Tobin's Q.

Regarding the effect of LEV, SAL, and SIZE as control variables on ROA, model (1) in Table (5) indicates that the coefficient of LEV is significant and negative, which means that the increase in LEV decreases ROA, the coefficient of SAL is significant and positive, this means that the increase in SAL positively affects the ROA, and also the coefficient of SIZE is negative, which shows a significant negative effect on ROA, these results are in line with (Abdul Rasheed et al, 2019), who found that SAL positively affects the ROA of the Indian firms, while LEV has a negative effect, also, these results are partly consistent with (Abdul Elwahab et al, 2011) who concluded that LEV has a negative effect on the ROA of the Malaysian firms, while SIZE has a positive effect. Moreover, Model (2) in Table (5) shows the effect of LEV, SAL, and 


\section{Karim Mansour Ali Hassouba}

SIZE on Tobin's Q, the coefficient of SIZE is significant and positive, while the effect of LEV and SAL is insignificant, these results are partly in agreement with (Hendratama and Barokah, 2020) who found that SIZE and LEV positively affect the Indonesian firm value.

Respecting the further analysis conducted to examine the influence of transaction type and RP type on FP, model (5) indicates a significant positive effect of purchase transactions with RPs on ROA, and a significant negative effect of sale transactions, this result is not consistent with (Hwang and Kim, 2016) and also (Abdul Rasheed et al, 2019) who find that revenue from RPs positively influences FP, also, model (5) reveal a significant negative effect of financing transactions on ROA, while model (6) mark insignificant effect for transaction types on Tobin's Q except the negative effect of financing transactions, these results are not in agreement with (Hendratama and Barokah, 2020) who find an effect for RP sales on firm value. Regarding the effect of RP types on FP, model (7) shows a positive effect of the transactions with board/management and associates on ROA, while the effect is negative for transactions with the joint venture, concerning the effect on Tobin's Q, model (8) indicates a negative effect of the transactions with each of subsidiaries, joint ventures and associates on Tobin's Q.

\section{Conclusion}

The results of the previous research show a debate regarding the effect of RPTs on FP, RPTs can have a negative impact on FP through the opportunistic behavior conducted by managers and exploiting the firm resources, RPTs may positively affect the FP by reducing the cost of the transaction and facilitating the movement of goods and services between the parties, RPTs may also be considered as normal transactions and do not affect FP, this research endeavors to investigating the influence of RPTs on the Egyptian FP, and examine the effect of AQ on this relation, it also seeks to test the impact of transaction type and RP type on FP.

This research conducted using a sample consists of 105 Egyptian firms with total observations of 735 from 2013 to 2019, the results indicate that RPTs have a negative effect on FP (whether it was measured by ROA or Tobin's Q), the results also reveal that AQ affects the relation 
Scientific Journal for Financial and Commercial Studies and Researches

(SJFCSR) Faculty of Commerce - Damietta University

between RPTs and FP, this effect is positive on ROA and negative on Tobin's Q. The additional tests show a positive effect of purchase transactions with RPs on ROA, and a negative effect of sale transactions on ROA, also there is a negative effect of the financing transactions on ROA and Tobin's Q. Concerning the effect of RP type, the results reveal that transactions with management/board and associates have a positive effect on ROA, and transactions with the joint ventures have a negative effect. Besides, the results indicate a negative effect of the transactions with the subsidiaries, joint ventures and associates on Tobin's Q. About the impact of the control variables, the results indicate that LEV affects ROA negatively, while SAL has a positive effect, SIZE has a negative effect on ROA and a positive effect on Tobin's Q.

This research contributes to the existing literature as follows: (1) it adds to the very few studies conducted in Egypt that examined the effect of RPTs on FP by investigating this relation using a relatively large sample and also test the role of AQ as a determinant of this relation; (2) it provides evidence that the effect of RPTs varies from a firm to another based on the type of audit firm; (3) it is important for policymakers and investors, as it provides evidence about the consequences of the RPTs; (4) it merges the accounting and market-based measurements when measuring the FP, where it measures the short and long FP, therefore, it provides a clear and comprehensive picture of the FP, (5) finally, this research adds to the literature of RPTs which indicated mixed results regarding the effect on FP, by providing evidence from the emerging markets, and test one of the determinants of this relation.

However, there are some limitations of this research; where it does not examine other factors that may affect the relation between RPTs and FP, also, it does not including unlisted Egyptian firms and banks in the sample. Hence, there are suggestions for future research to test other moderating variables on this relation like board characteristics, ownership structure and political connections, in addition to investigating the impact of RPTs on the performance of Egyptian banks, and also, examine the impact of RPTs on audit risk, earnings management, and dividend policy. 


\section{Karim Mansour Ali Hassouba}

\section{References}

Al-Matari, E, M. Al-Swidi, A, K. Hanim, F. (2014). The measurements of firm performance's dimensions. Asian journal of finance and accounting. 6 (1), 24-49.

Abdul Wahab, E.A., Haron, H., Lok, C.L., and Yahya, S. (2011). Does corporate governance matter? Evidence from related party transactions in Malaysia. Advances in Financial Economics. 14, 131-164.

Abdullatif, M., Alhadab, M., \& Mansour, I. (2019). Determinants of Related Party Transactions in Jordan: Financial and Governance Factors. Australasian Accounting, Business and Finance Journal. 13 (1), 44-75.

Amzaleg, Y., Barak, R. (2013). Ownership concentration and the value effect of related party transactions. Journal of modern accounting and auditing. 9 (2), 239-255.

Al Manaseer, M. F. A., Al-Hindawi, R. M., Al-Dahiyat, M. A., \& Sartawi, I. I. (2012). The impact of corporate governance on the performance of Jordanian banks. European Journal of Scientific Research. 67 (3), 349-359.

Ali. A. A, (2015). The relation between disclosure level of related party transaction and financial reporting quality: evidence from Egyptian listed firms. Accounting Thinking Journal. 2, 3-75.

Al-Suraifi, A, A. (2016) the effect of accounting disclosure level of related party transactions on firm value: evidence from listed Egyptian firms. Journal of accounting thinking. Ain shams university. 2, $125-167$.

Abdul Rasheed, P, C., Mallikarjunappa, T, Thomachan, K, T. (2019). Promoter Ownership, Related Party Transactions and Firm Performance: A Study Among Selected Companies in India. FIIB Business Review. 8 (3), 205- 217.

Bennouri, M., Mehdi, N., Philippe, T., (2015). Does Auditor Reputation "Discourage" Related-Party Transactions? The French Case. Auditing: A Journal of practice \& theory. 34 (4), 1-32. 
Scientific Journal for Financial and Commercial Studies and Researches (SJFCSR) Faculty of Commerce - Damietta University

Bozcuk, A. E. (2011). Performance effects of outside directors on corporate boards. International Journal of Business and Social Science. 2 (20), 80-84.

Bhuiyan, M. B. U., \& Roudaki, J. (2018). Related party transactions and finance company failure: New Zealand evidence. Pacific Accounting Review. 30 (2), 199-221.

Bona-Sánchez, C., Fernández-Senra, C. L., \& Pérez-Alemán, J. (2017). Related-party transactions, dominant owners and firm value. BRQ Business Research Quarterly. 20 (1), 4-17.

Chien, C.-Y., and Hsu, J.C. (2010). The role of corporate governance in related party transactions. SSRN ELibrary.

Chang, S.J. and Hong, J. (2000). Economic performance of groupaffiliated companies in Korea: Intragroup resources sharing and internal business transaction. Academy of Management Journal. 43 (3), 429-434.

Chen, J.J., Cheng, P. and Xiao, X. (2011). Related party transactions as a source of earnings management. Applied Financial Economics. 21 (3), 165-181.

Diab, A., Aboud, A., and Hamdy, A. (2019). The impact of related party transactions on firm value: Evidence from a developing country. Journal of Financial Reporting and Accounting. 17 (3), 571-588.

Dyck, A. and Zingales, L. (2004). Private benefits of control: An international comparison. The Journal of Finance. 59 (2), 537-600.

El-Helaly, M. (2014). Corporate governance and related party transactions research: An assessment of theories and methodologies, Corporate Ownership and Control. 11 (2), 578-582.

(2018). Related-party transactions: a review of the regulation, governance and auditing literature. Managerial Auditing Journal. 33 (8/9), 779-806.

Francis, J. R., Yu, M. D., (2009). Big 4 office size and audit quality. The accounting review. 84 (5), 1521-1552. 


\section{Karim Mansour Ali Hassouba}

Gordon, E.A., Henry, E., and Palia, D. (2004). Related party transactions: associations with firm value. Advances in Financial Economics. 9, $1-27$.

Habib, A. and Muhammadi, A. (2018), "Political connections and audit report lag: Indonesian evidence", International Journal of Accounting and Information Management, Vol. 26 No. 1, pp. 5980 .

Huang, W. (2016). Tunnelling through related-party loan guarantees: Evidence from a quasi-experiment in China. Review of Quantitative Finance and Accounting. 47 (3), 857-884.

Henry, E. A., Gordon, B. and T. Louwers. (2007). the Role of Related Party Transactions in Fraudulent Financial Reporting. http://ssrn.com/abstract=993532.

Hwang, S., \& Kim, W. (2016). When heirs become major shareholders: Evidence on pyramiding financed by related-party sales. Journal of Corporate Finance. 41, 23-42.

Hendratama, T, D. Z, Barokah. (2020). related party transactions and firm value: The moderating role of corporate social responsibility reporting. China Journal of Accounting Research. 13, 223-236.

International Accounting Standards Board (IASB). (2013). International Accounting Standard 24 - Related Party Disclosures. London, United Kingdom: IASB.

Jian, M. and Wong, T.J. (2010). Propping through related party transactions. Review of Accounting Studies. 15 (1), 70-105.

Kuan, L., Tower, G., Rusmin, R. and Van der Zahn, J. W. M. (2010). Related party transactions and earnings management. Jurnal Akuntansi dan Auditing Indonesia. 14 (2), 115-137.

Karaca, S. S., \& Ekşi, İ. H. (2012). The relationship between ownership structure and firm performance: An empirical analysis over İstanbul Stock Exchange (ISE) Listed Companies. International Business Research. 5 (1), 172-181.

Kang, S., \& Kim, Y. (2011). Does earnings management amplify the association between corporate governance and firm performance? 
Scientific Journal for Financial and Commercial Studies and Researches (SJFCSR) Faculty of Commerce - Damietta University

Evidence from Korea. International Business \& Economics Research Journal. 10 (2), 53-67.

Lin WY, Liu YA, Keng I. (2010). Related party transactions, firm performance and control mechanisms: Evidence from Taiwan. International Research Journal of Finance and Economics. 35, 8298.

Lee, M. G., Kang, M., Lee, H. Y., \& Park, J. C. (2016). Related party transactions and financial statement comparability: Evidence from South Korea. Asia-Pacific Journal of Accounting and Economics. 23 (2), 224-252.

Limanto, G., Herusetya, A. (2017). The association between related party transaction and real earning management: internal governance mechanism as moderating variables, SHS web of conferences.

Marchini, P. L., Mazza, T., \& Medioli, A. (2018). The impact of related party transactions on earnings management: some insights from the Italian context. Journal of Management and Governance. 22 (4), 981-1014.

Mayhew B. Kohlbeck M. (2010). Valuation of Firms that Disclose Related Party Transactions. Journal of Accounting and Public Policy. 29 (2), 2010, 115-137.

Pozzoli, M., \& Venuti, M. (2014). Related party transactions and financial performance: Is there a correlation? Empirical evidence from Italian listed companies. Open Journal of Accounting. 3 (1), 28-37.

Pizzo M., (2013). Related Party Transactions under a Contingency Perspective. Journal of Management \& Governance. 17 (2), 309330.

Rouf, M. A. (2011). The relationship between corporate governance and the value of the firm in developing countries: Evidence from Bangladesh. The International Journal of Applied Economics and Finance. 5 (3), 237-244.

Rmili, S, M. (2018). The impact of importance and level of disclosure of related party transactions on earnings quality: an empirical study on 


\section{Karim Mansour Ali Hassouba}

listed Egyptian companies. Auditing and accounting journal. 1, 1 34.

Srinivasan, P. (2013). An analysis of related-party transactions in India. IIM Bangalore Research Paper, (402).

Sutrisno T, S. Saraswati, E. Purnomosidhi, B. (2019). The effect of related party transactions on firm performance: the moderating role of political connection in Indonesian banking. Business: theory and practices. 20, 81-92. ISSN 1648-0627 / eISSN 1822-4202.

Shastri K. and K. M. Kahle, (2004). Executive Loans. AFA San Diego Meetings", EFA Annual Conference Paper. No. 184, http://ssrn.com/abstract=423447 (Accessed 11/3/2019).

Shan, Y. G., \& McIver, R. P. (2011). Corporate governance mechanisms and financial performance in China: panel data evidence on listed non-financial companies. Asia Pacific Business Review. 17 (3), 301-324.

Sharaf, A, A. (2020). The effect of related party transactions on the relation between accounting information and stock prices: evidence from Egyptian listed firms. Alexandria journal for accounting researches. $1,1-47$.

The Egyptian guide of corporate governance. (2016). Egyptian institute of directors. Egyptian financial supervisory authority (EFSA).

The Egyptian financial regularity authority (EFRA). (2008). Egyptian auditing standard No 550, Related parties.

$$
\text { (2008), Egyptian accounting standard No } 15 .
$$

Disclosure of related parties.

(2020). rules for registering and writing off securities on the Egyptian Stock Exchange.

Tambunan ME, Siregar H, Manurung AH, Priyarsono DS. (2017) Related party transactions and firm value in the business groups in the Indonesia stock exchange. Journal of Applied Finance and Banking 7 (3), 1-20. 
Scientific Journal for Financial and Commercial Studies and Researches (SJFCSR) Faculty of Commerce - Damietta University

T. Khanna and K. Palepu. (2017). Why Focused Strategy May be Wrong in Emerging Markets. Harvard Business Review. 75 (4), 41-51.

Utama S, Utama CA, Yuniasih R. (2010). Related party transactionefficient or abusive: Indonesia evidence. Asia Pacific Journal of Accounting and Finance. 1, 77-102.

Wong, R. M., Kim, J. B., \& Lo, A. W. (2015). Are related $\square$ party sales value $\square$ adding or value $\square$ destroying? Evidence from China. Journal of International Financial Management \& Accounting. 26 (1), 1-38.

Williams, M. P., \& Taylor, D. W. (2013). Corporate propping through related-party transactions. International Journal of Law and Management. 55 (1), 28-41.

W. Ge, D. H. Drury, S. Fortin, F. Liu and D. (2010). Tsang. Value Relevance of Disclosed Related Party Transactions. Advances in Accounting. 26 (1), 134-141.

Yaron, A., Uri, B.-Z., \& Ahron, R. (2016). Tunnelling or propping? Evidence for related party transactions. International Journal of Management Sciences. 7 (6), 332-349. 


\title{
Karim Mansour Ali Hassouba
}

\section{أثر المعاملاتمع الأطراف ذوى العلاقت على أداء الشركات المصريتة : دور جودة المراجعت أملمي}

\author{
د. كريم منصور علي حسوبة \\ مدرس بقسم المحاسبة ـ كلية التجارة - جامعة القاهرة \\ karimmansour@foc.cu.edu.eg
}

\begin{abstract}
المستخلص

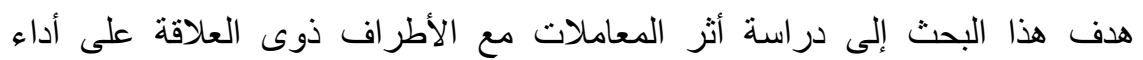

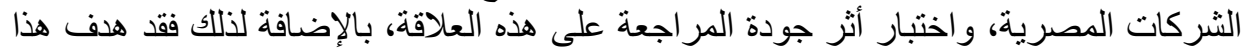

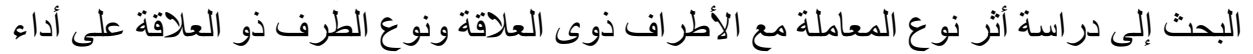

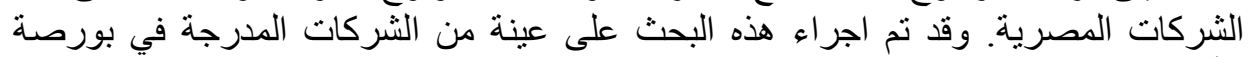

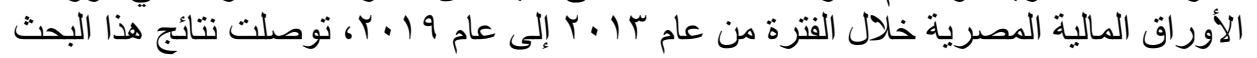

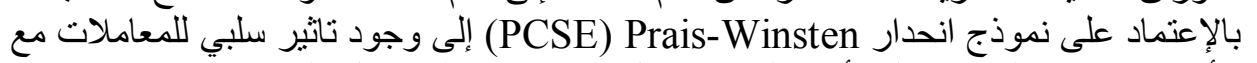

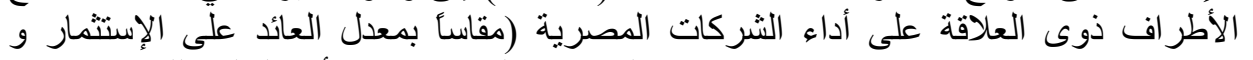

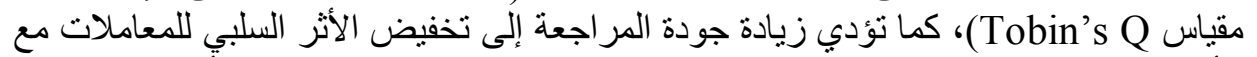

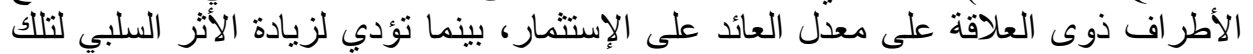

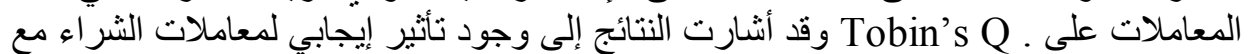

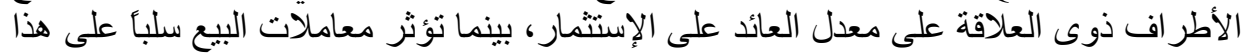

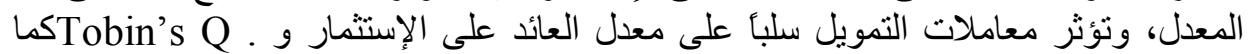

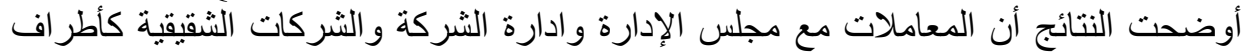

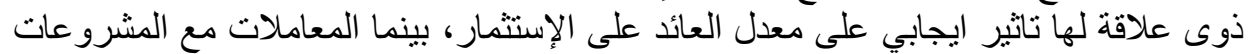

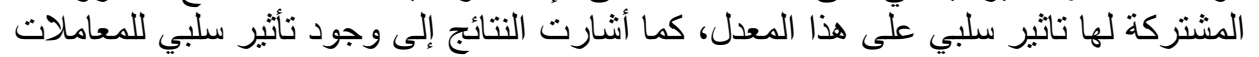

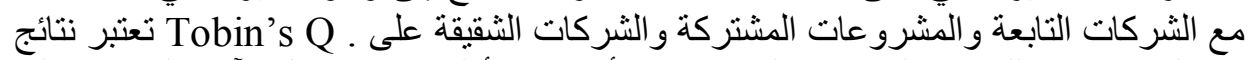

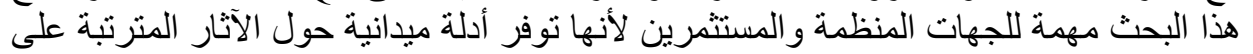

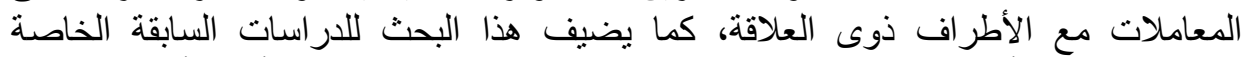

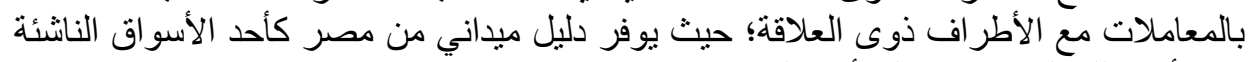
عن نأثير تلأك المعاملات على الأداء الثراء الثركات. الكلمات المفتاحيتة: المعاملات مع الأطراف ذوى العلاقة، جودة المراجعة، أداء الثركات،

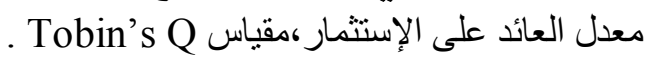

